\title{
Topical Paste Dosage Form
}

National Cancer Institute

\section{Source}

National Cancer Institute. Topical Paste Dosage Form. NCI Thesaurus. Code C149414.

Semi-solid single-dose or multidose preparation containing a large proportion of finely divided solids dispersed in the basis, intended for cutaneous use. 